\title{
Optimization of Enzyme Assisted Extraction of Chondroitin Sulfate from Bohadschia argus by Response Surface Methodology
}

\author{
Thanagorn Ruensodsai ${ }^{1}$, Elizabeth Jayex Panakkal $^{2}$, Prawpan Teerapornnarong ${ }^{2}$, Wawat Rodiahwati $^{3}$, Malinee \\ Sriariyanun ${ }^{2,4 *}$, Kittipong Rattanaporn ${ }^{1 *}$ \\ ${ }^{1}$ Department of Biotechnology, Faculty of Agro-industry, Kasetsart University, Bangkok, Thailand \\ ${ }^{2}$ Department of Mechanical and Process Engineering, The Sirindhorn International Thai-German Graduate School of Engineering \\ (TGGS), King Mongkut's University of Technology North Bangkok (KMUTNB), Bangkok, Thailand \\ ${ }^{3}$ Department of Chemistry, University of New England: Armidale, New South Wales, Australia \\ ${ }^{4}$ Biorefinery and Process Automation Engineering Center (BPAEC), King Mongkut's University of Technology North Bangkok, \\ Bangkok, Thailand
}

\begin{abstract}
Chondroitin sulfate is currently one of the bioactive compounds obtained from different natural materials with high benefit in human medical treatment and pharmaceutical. However, the natural concentration of chondroitin sulfate in high cost raw material is low and this situation makes the commercialization become difficult. This study focused on production of chondroitin sulfate isolated from Bohadschia argus using enzyme-assisted extraction methodology. Optimization experiments were conducted based on Response Surface Methodology (RSM) using Box-Behnken design (BBD). Three important extraction parameters, including enzyme concentration $\left(\mathrm{X}_{1}: 0.05-0.5 \%\right)$, Time $\left(\mathrm{X}_{2}: 0.25-3 \mathrm{~h}\right)$, and temperature $\left(\mathrm{X}_{3}: 55-65{ }^{\circ} \mathrm{C}\right)$ were varied to obtain maximum chondroitin sulfate yields. The RSM optimized model obtained from statistical analysis presented the high correlation coefficiency (R2) at 0.7508 , advocating the significance of the model. The optimum extraction conditions were selected as enzyme concentration of $0.48 \%$ with extraction time of $1.01 \mathrm{~h}$. at an extraction temperature of $56.53{ }^{\circ} \mathrm{C}$. Under these conditions, the experimental yield of chondroitin sulfate was $415.59 \mathrm{mg} / 100 \mathrm{~g}$ dry, which is in good agreement with the value predicted by the model.
\end{abstract}

Keyword. Sea cucumber, Chondroitin sulfate, Response surface methodology, Papain, Extraction

\section{INTRODUCTION}

Osteoarthritis clinical studies confirmed the therapeutic effects of orally taken chondroitin sulfate on osteoarthritis patients with improvement of joint function and pain reduction [1-2]. Chondroitin sulfate is present abundantly in the extracellular matrix of cartilaginous tissues and connective tissue, which are composed of collagen networks and amorphous ground substance including glycoproteins, hyaluronan, proteoglycans [3]. Chondroitin sulfate is an acid mucopolysaccharide, a macrobiomolecule, that is comprehensively used in medicine, biological materials, cosmetics, and other fields for its unique pharmacological activities [4], such as anti-inflammatory, anticancer [5]. In general, chondroitin sulfate can be added in cosmetic products as a moisturizing agent. Due to the large amount of negative charge within the chondroitin sulfate molecule, the repulsions create a gap causing water and nutrients to retain within the molecule's empty space. Therefore, chondroitin sulfate is very effective in maintaining moisture [6]. Being a water-soluble biopolymer, it has the potential to retain the moisture in skin and replace the conventionally used glycerin from moisturizers.

Currently, the commercial product of chondroitin sulfate is derived from shark, cow, pig and chicken cartilage, etc. The main benefits for utilizations of these biomaterials are to increase the value of bio-wastes and to reduce the disposal of wastes to environment and to reduce the workloads of waste management. It is widely being used in cosmetic industry and as a dietary supplement. However, the current problem is due to the chance of infectious disease outbreaks such as Mad cow disease and $\mathrm{H} 1 \mathrm{~N} 1$ virus caused by poor preparing raw materials. Furthermore, the religious or social restrictions on animal sources such as pork, cow or shark are the reasons to seek for alternative source for chondroitin sulfate production.

Marine sources have been demonstrated to be the raw materials of bioactive compounds with numerous health benefits and high level of biodiversity. In these recent years, extensive studies have been conducted to investigate biological activities, nutritional value, and potential health benefits of marine based bioactive 
substances [7-8]. Marine living organisms produced biological compounds, especially sulfated polysaccharides with anticoagulant, antithrombotic activities [9]. Several researches are conducted to harvest bioactive compounds from sea cucumbers because this natural meat source is one of staple food in Asian countries due to its high good fatty acid and collagen and it is included in Ayuravedic medicine [10-11].

Sea cucumbers are a good alternative to the future production of chondroitin sulfate. Among large variation of chondroitin sulfate, there are two main types of sulfated polysaccharide in the body wall sea cucumber namely fucans (SF) often named "fucoidans" and fucosylated chondroitin sulfates (FuCS) (Figure 1). FuCS obtained from sea cucumbers are characterized to be polymeric molecules of D-glucuronic acid, N-acetylD-galactosamine, L-fucose, and sulfate residues [12]. Interestingly, FuCS isolated from the body wall of sea cucumbers are structurally different from sulfated polysaccharides in other invertebrates [13]. The molecular structures and biological activities of FuCS can vary depending on the species. However, the extraction process of chondroitin sulfate has been demonstrated mostly in laboratory scale.

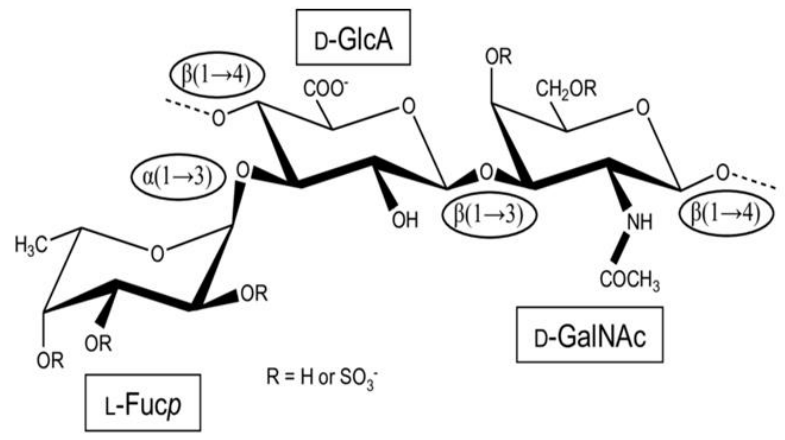

Fig. 1. Fucosylated chondroitin sulfates (FucCS)

From the past reports of chondroitin sulfate extraction, there are different extraction methods depending on the type of raw material, such as extraction of chondroitin sulfate using acids, alkaline [14] or extraction under high pressure and enzymatic extraction. Generally, proteolysis methods are used to release peptides of glycosaminoglycans (GAGs) from their tissues [3]. For this purpose, many researchers use an overly expensive proteinase namely, papain. An alternative and more economical enzyme is required to substitute this costly enzyme to reduce the cost of extraction. Moreover, cleavage of core protein of proteoglycan depends on the types of proteolytic enzymes. The size of peptides greatly depends on the proteolytic enzyme used [3].

The major drawbacks of conventional methods, acid or alkali extraction, include breaking of bonds between xylose and serine resulting in the release of sulfate and chondroitin from their extracellular matrix. This makes it difficult to detect CS after digestion. However, these CS molecules which are released free, can be easily absorbed by human digestive system. Enzymatic extraction was demonstrated to be able to overcome this problem because enzymes digest only in the specific regions of the substrates. Hence, using different enzymes provide different end products of CS and CS biological activities.

Therapeutic capability of the orally ingested CS has been proved by the clinical studies conducted on osteoarthritis patients. These patients had pain reduction and improvement in joint function by intake of CS [1517]. Therapeutic effects of bovine derived CS (C4S and C6S) as a drug has also been proved by its oral intake at a dose of $800 \mathrm{mg} /$ day in regular intervals, twice a year [18]. The cartilaginous rings of bovine trachea, pork ears and snout and shark cartilage are used as sources of CS in nutritional supplements. Other available sources of CS have been investigated by many researchers [19-22], also different methods for extraction and analysis of CS have been reported [23-27]

This study was aimed to investigate the Papainassisted extraction method of chondroitin sulfate from sea cucumber, Bohadschia argus, based on Response Surface Methodology (RSM) with Box-Behnken design (BBD), a widely used statistical technique [28][29-30]. This study could provide new insights in the production of CS from sea cucumber under optimized conditions using papain. The extracted CS can be further applied in the nutraceutical and functional food industry [31].

\section{MATERIAL AND METHODS}

\subsection{Sample prepareation}

Samples of dried Tigerfish (Bohadschia argus) were delivered from Papua New Guinea to the laboratory (Courtesy provided by Wonnapob Co., Ltd., Bangkok, Thailand) (Figure 2). The dried weight and the wet weight were measured and recorded. For the wet weight, the sea cucumbers were rehydrated, by putting sea cucumber into deionized water for 96 hours at $4{ }^{\circ} \mathrm{C}$. Deionized water was changed every 24 hours. Weight was recorded and the moisture content was analyzed. The sea cucumbers were sliced into small pieces and stored at $-20{ }^{\circ} \mathrm{C}$. Food grade Papain (EC 3.4.22.2), chondroitin-4-sulfate from bovine trachea (Fluka) was used as standards. 1,9-Dimethylmethylene blue was purchased from Aldrich. All the other reagents used in the experiment were analytical grade.

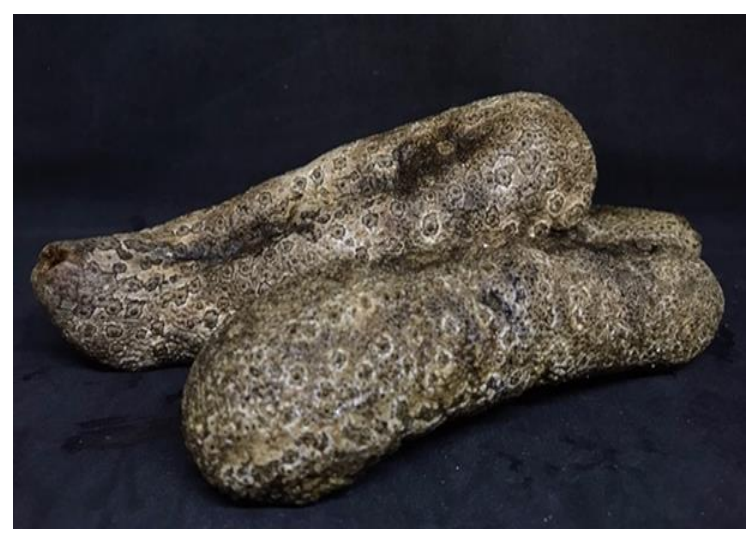

Fig. 2. Tiger fish sea cucumber (Bohadschia argus) 


\subsection{Enzyme extraction of chondroitin sulfate}

Extraction of proteins depends on two vital elements, namely extraction condition and the specificity of the enzyme. A previous study on defatted Lemna minor has demonstrated that protein recovery, degree of hydrolysis values and antioxidant properties of hydrolysed proteins could be enhanced by increasing enzyme concentration and hydrolysis time [32]. During enzyme assisted extraction, protein and glycan sulfate present in the connective tissue of sea are broken-down to release chondroitin sulfate free. Chondroitin sulfate was extracted by a method modified from Garnjanagoonchorn et al. [30].

Initially, the sea cucumber was cut into about 1 $\mathrm{cm}$-sized slices. $2.0 \mathrm{~g}$ of sliced sea cucumber was blended in a homogenizer with $0.1 \mathrm{M}$ sodium phosphate buffer containing $0.005 \mathrm{M}$ Ethylenediaminetetraacetic acid, $0.005 \mathrm{M}$ cysteine hydrochloride, and $0.02 \%$ sodium azide for preservation of raw material in extraction process. In addition to this, sodium phosphate buffer can maintain the ionic environment required for extraction process. $\mathrm{pH}$ of the buffer was adjusted to 7.0 and Papain enzyme was added into mixture. Enzyme hydrolysis treatment was carried out according to Box-Behnken Design (BBD). The sample was taken after stopping the enzyme reaction with boiling water at $95^{\circ} \mathrm{C}$.

\subsection{Experimental design}

Optimization of parameters for the extraction of chondroitin sulfate from Bohadschia argus was carried out based on RSM with Box-Behnken design (BBD) by using the Design-Expert software (V.7.0.0, Stat- Ease, Inc, Minneapolis, USA). This model has been widely used to evaluate the relationships between response values and factors [5] Furthermore, this method has the benefit of reducing the number of experiments. The selected extraction parameters in this work included the concentration of enzyme, extraction time, and extraction temperature. The range and center point values of the three independent variables were presented in (Table 1.) The three factors were assigned as enzyme concentration $\left(\mathrm{X}_{1}\right)$, extraction times $\left(\mathrm{X}_{2}\right)$, and extraction temperature $\left(\mathrm{X}_{3}\right)$ and varied to three levels, coded $+1,0$, and 1 for high, intermediate, and low values, respectively. A total of 17 experimental runs were carried out according to this design in (Table 2) for optimization of the extraction process. The extraction yield of chondroitin sulfate was selected as the response $(\mathrm{Y})$.

Table 1. Factor and level of Box-Behnken design

\begin{tabular}{|l|c|c|c|c|}
\hline \multirow{2}{*}{ Factor } & \multirow{2}{*}{$\begin{array}{c}\text { Coded } \\
\text { symbols }\end{array}$} & \multicolumn{3}{|c|}{ Levels } \\
\cline { 3 - 5 } & $\mathrm{X}_{1}$ & 0.05 & 0.253 & 0.5 \\
\hline Concentration $(\%)$ & $\mathrm{X}_{2}$ & 0.25 & 1.625 & 3 \\
\hline Time $($ min $)$ & $\mathrm{X}_{3}$ & 55 & 60 & 65 \\
\hline Temperature $\left({ }^{\circ} \mathrm{C}\right)$ & & \multicolumn{3}{|c}{}
\end{tabular}

The ranges of each factor were selected based on our preliminary studies. The temperature range was set between 55 to $65^{\circ} \mathrm{C}$. Even though the enzyme is active in room temperature $\left(+/-20^{\circ} \mathrm{C}\right)$, the optimal papain activity was observed between 55 to $65^{\circ} \mathrm{C}$. Higher temperature above $65{ }^{\circ} \mathrm{C}$ may lead to inactivation of enzyme which led to setting temperature range between 55 and $65{ }^{\circ} \mathrm{C}$. Extraction time can depend on raw material used for study. Extraction of chondroitin sulfate from bovine cartilage require an extraction time was 48 hours due to differences in the raw material used in the extraction process. However, extraction from sea cucumber does not require too long incubation. Therefore, the extraction time was limited between 0.25 to 3 minutes. Enzyme concentration was chosen according to the previous study from Nguyen et al. within range of 0.2 to $1 \%$. [33]

Table 2. Experimental design and responses of the dependent variables to extraction conditions

\begin{tabular}{|c|c|c|c|c|}
\hline Run & $\begin{array}{c}\text { Factor } 1 \\
\mathrm{X}_{1}: \\
\text { Concentration } \\
(\%)\end{array}$ & $\begin{array}{c}\text { Factor } \\
2 \\
\mathrm{X}_{2}: \\
\text { Time } \\
(\mathrm{min})\end{array}$ & $\begin{array}{c}\text { Factor } 3 \\
\mathrm{X}_{3}: \\
\text { Temperature } \\
\left({ }^{\circ} \mathrm{C}\right)\end{array}$ & $\begin{array}{c}\text { Yields } \\
(\mathrm{mg} / 100 \mathrm{~g} \\
\text { dry })\end{array}$ \\
\hline 1 & 0.50 & 1.63 & 55 & 426.98 \\
\hline 2 & 0.01 & 0.25 & 60 & 252.28 \\
\hline 3 & 0.50 & 3.00 & 60 & 343.69 \\
\hline 4 & 0.25 & 0.25 & 55 & 395.28 \\
\hline 5 & 0.25 & 1.63 & 60 & 392.24 \\
\hline 6 & 0.25 & 3.00 & 65 & 349.58 \\
\hline 7 & 0.25 & 1.63 & 60 & 410.03 \\
\hline 8 & 0.01 & 1.63 & 55 & 272.92 \\
\hline 9 & 0.25 & 1.63 & 60 & 393.07 \\
\hline 10 & 0.01 & 1.63 & 65 & 407.82 \\
\hline 11 & 0.25 & 1.63 & 60 & 429.93 \\
\hline 12 & 0.25 & 1.63 & 60 & 443.93 \\
\hline 13 & 0.25 & 3.00 & 55 & 432.88 \\
\hline 14 & 0.01 & 3.00 & 60 & 362.85 \\
\hline 15 & 0.25 & 0.25 & 65 & 409.29 \\
\hline 16 & 0.50 & 1.63 & 65 & 437.30 \\
\hline 17 & 0.50 & 0.25 & 60 & 404.13 \\
\hline
\end{tabular}

\subsection{Determination of chondroitin sulfate}

The content of chondroitin sulfate was determined by dimethylmethylene blue assay (DMMB) according to the procedure defined by Thomas-Coulson et al. [34]. Different concentrations $0,2,4,6,8 \mu \mathrm{g} / \mathrm{ml}$ of chondroitin-4-sulphate (C4S) was used as standard curve for quantitative calculation (Figure 3). Stock solutions were prepared along with DMMB dye and was pipetted into 96 well microplates. The volume was adjusted to 20 $\mu \mathrm{l}$ with deionized water. A volume of $20 \mu \mathrm{l}$ from each extracted chondroitin sulfate sample was pipetted out in subsequent wells containing $200 \mu \mathrm{l}$ of DMMB dye in the microplate followed by shaking of the microplate for 5 seconds using a microplate shaker. The absorbance was recorded using UV-Vis spectrophotometer at $525 \mathrm{~nm}$ immediately and plotted against the concentration on a graph and the CS content was determined by referring to the standard graph. The standard curve selected the chondroitin sulfate as a standard, and the regression equation was $\mathrm{Y}=0.0382 \mathrm{X}+0.0116$ with $\mathrm{R}^{2}=0.9901$ 


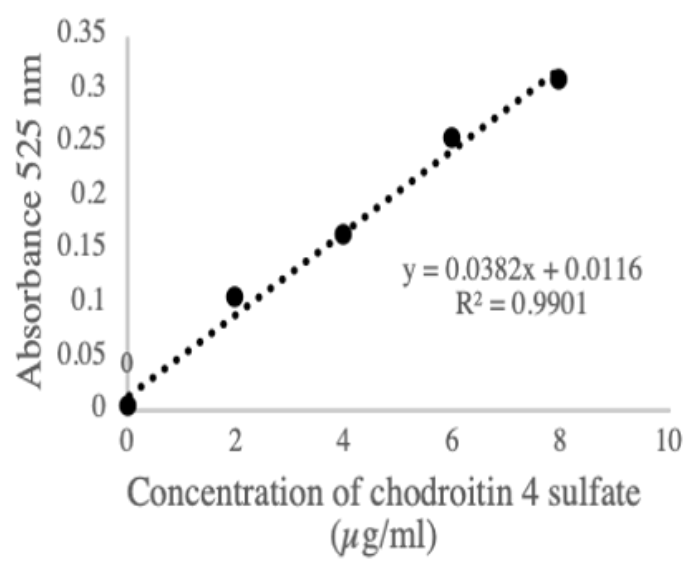

Fig. 3. Standard curve for quantitation of chondroitin sulfate

\section{RESULT AND DISCUSSION}

Optimization of extraction conditions of chondroitin sulfate from Bohadschia argus was conducted based on RSM. Before conducting the RSM, the levels of RSM independent variables for chondroitin sulfate extraction were determined based on the preliminary experiments (data not shown). After preliminary experiments, 17 experimental runs with three independent variables, and three levels were conducted according to the BoxBehnken design (BBD) as shown in (Table 2). The independent variables were enzyme concentration $\left(\mathrm{X}_{1}\right)$, extraction times $\left(\mathrm{X}_{2}\right)$, and extraction temperature $\left(\mathrm{X}_{3}\right)$ while the response variable $(\mathrm{Y})$ was the amount of chondroitin sulfate from the Bohadschia argus.

The application of the RSM offered a model representing an empirical relationship between the response variable (extraction rate of CS) and the test variables under targeted investigation. Table 2 represented the yields of CS under different 17 extraction conditions. It was found that the highest yield of CS from RSM experiment was $443.93 \mathrm{mg} / 100 \mathrm{~g}$ from run number 12 and the lowest yield was $252.28 \mathrm{mg} / 100$ $\mathrm{g}$ from run number 2 .

The significance of the model was determined by ANOVA analysis (Table 3) suggesting the quadratic model to fit with experimental data. The P-value of the model was less than 0.0001, which suggested the significance of the used model. The high correlation coefficiency $\left(\mathrm{R}^{2}\right)$ at 0.7508 of the predicted model was obtained, advocating the significance of the model. Furthermore, Lack of Fit test showed insignificant pvalue at 0.2619 , which was in good agreement to model $\mathrm{p}$-value and $\mathrm{R}^{2}$. In case of term models, enzyme concentration $\left(\mathrm{X}_{1}\right)$ and Time $\mathrm{x}$ Temp were statistically significant (P-value $<0.1)$. By applying regression analysis on the experimental data, the response variable (CS yield) and the test variables (extraction parameters) were related by the following second order polynomial equation $\mathrm{Y}=-2120.22564+1535.51868 * \mathrm{X}_{2}+$ $6872.55469 * \mathrm{X}_{1}+36.47787 * \mathrm{X}_{3}-94.02424 * \mathrm{X}_{1} * \mathrm{X}_{3}$ $-463.95372 * \mathrm{Time}^{2}-1637.79206 * \mathrm{X}_{1}$
Table 3. ANOVA for response surface quadratic model

\begin{tabular}{|l|l|l|l|l|l|}
\hline Source & $\begin{array}{l}\text { Sum of } \\
\text { Squares }\end{array}$ & df & $\begin{array}{l}\text { Mean } \\
\text { Squares }\end{array}$ & $\begin{array}{l}\text { F } \\
\text { Value }\end{array}$ & $\begin{array}{l}\text { p- } \\
\text { value } \\
\text { Prob } \\
\text { F }\end{array}$ \\
\hline Model & $3.521 \mathrm{E}+0.006$ & 6 & $5.868 \mathrm{E}+005$ & 50.73 & $\begin{array}{l}< \\
0.0001\end{array}$ \\
\hline $\mathrm{X}_{2}$ & 11578.38 & 1 & 115793.38 & 1.00 & 0.3407 \\
\hline $\mathrm{X}_{1}$ & 79990.00 & 1 & 79990.00 & 6.91 & 0.0252 \\
\hline $\mathrm{X}_{3}$ & 32444.96 & 1 & 32444.96 & 2.80 & 0.1249 \\
\hline $\mathrm{X}_{2} \mathrm{X}_{3}$ & 54153.94 & 1 & 54153.94 & 4.68 & 0.0558 \\
\hline $\mathrm{X}_{1}{ }^{2}$ & $3.249 \mathrm{E}+006$ & 1 & $3.249 \mathrm{E}+006$ & 280.82 & $<$ \\
\hline $\mathrm{X}_{2}^{2}$ & 42497.11 & 1 & 42497.11 & 3.67 & 0.0843 \\
\hline Residual & $1.157 \mathrm{E}+005$ & 10 & 11568.36 & & \\
\hline $\begin{array}{l}\text { Lack of } \\
\text { Fit }\end{array}$ & 86751.68 & 6 & 14458.61 & 2.00 & 0.2619 \\
\hline $\begin{array}{l}\text { Pure } \\
\text { Error }\end{array}$ & 28931.88 & 4 & 7232.97 & & \\
\hline $\begin{array}{l}\text { Cor } \\
\text { Total }\end{array}$ & $3.637 \mathrm{E}+006$ & 16 & $5.868 \mathrm{E}+005$ & & \\
\hline
\end{tabular}

The normal distribution plot was conducted to examine the residuals of the data and analyzed the linearity of response distribution. The distribution of the residual values in Figure 4 showed that there was a linear distribution. It confirmed that the residues from the experimental results of the chondroitin sulfate yield extracted from the Bohadschia argus were normally distributed.

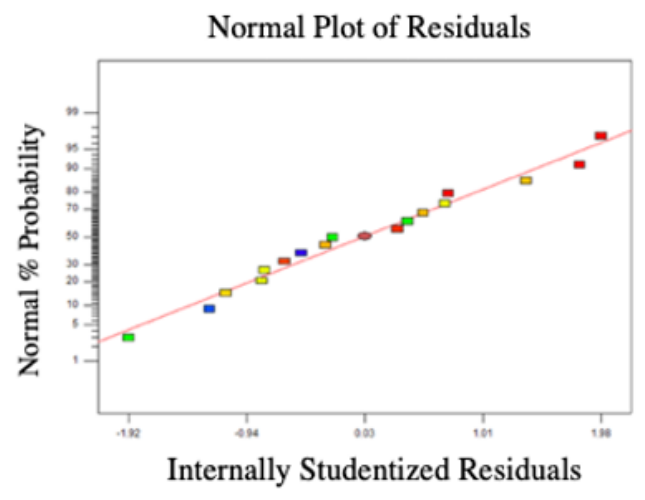

Fig. 4. Normal plot of residuals

The response surface plots between different independent variables and response were plotted to monitor the interactions of the variables and their effects on target response, CS yield. This response surface plot also determined the optimum level of each variable for the maximum response. The optimum values of the variables were obtained by solving the regression equation using the Design-Expert software. The 3D response surface plots and contour plots between different variables and yield of CS were represented in (Figure 5) and (Figure 6). Figure 5 showed the effect of enzyme concentration and extraction time on the yield of CS. From figure 5A, at the center point, where enzyme concentration was $0.25 \%$ and time 1.63 hours, a slight increase in the yield of CS was visible. It was also 
observed that the CS yield was increased with the increasing enzyme concentration.

This could be explained that the higher enzyme concentration caused a greater number of site-specific digestions leading to the release of more polysaccharides in a short extraction time. However, when the extraction time was extended, the trend of CS yield was different. With increasing extraction time, the yield of CS decreased, which could be due to the partial decomposition of the polysaccharide. This indicated that the shorter extraction time of enzyme concentration was suggested in this study for improving the extraction yield.

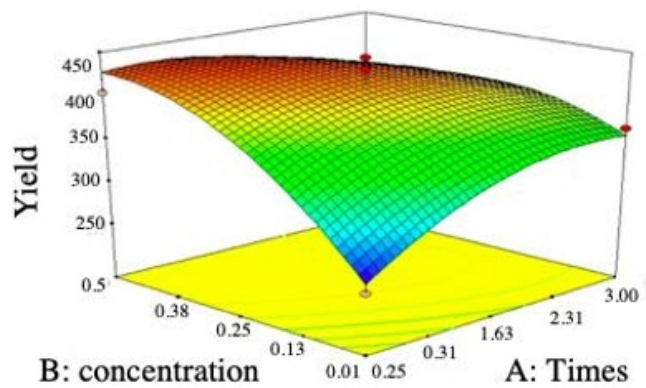

(B)

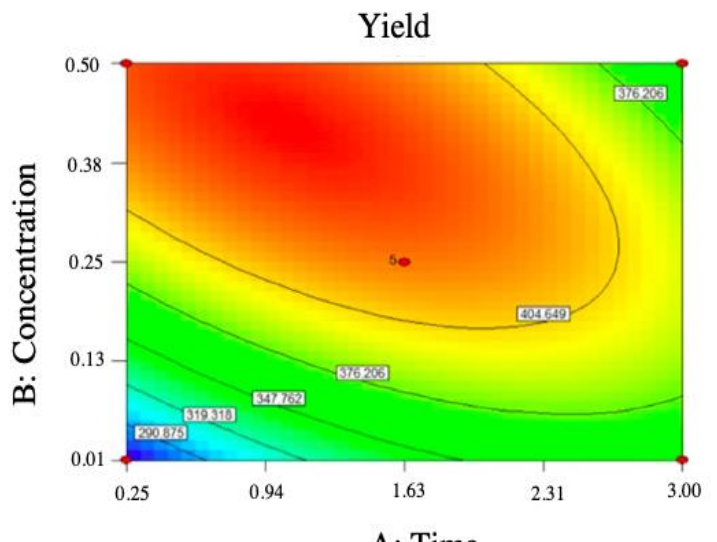

A: Time

Fig. 5. (A) 3D response surface and (B) contour picture plots between extraction parameters (concentration, times) and yield.

On the other hand, when enzyme concentration was fixed at the center point $(0.25 \%)$, CS yield was increased by increasing the extraction temperature from $55{ }^{\circ} \mathrm{C}$ to $60{ }^{\circ} \mathrm{C}$ (Figure 6). Figure 6 showed the correlation between enzyme concentration and extraction temperature on the $\mathrm{CS}$ yield at a fixed extraction temperature at $60{ }^{\circ} \mathrm{C}$. CS yield increased steadily when enzyme concentration increased from 0.035 to $0.25 \%$. However, the CS yield decreased when temperature exceeded $62{ }^{\circ} \mathrm{C}$, which may be due to decomposition of CS.
(A)

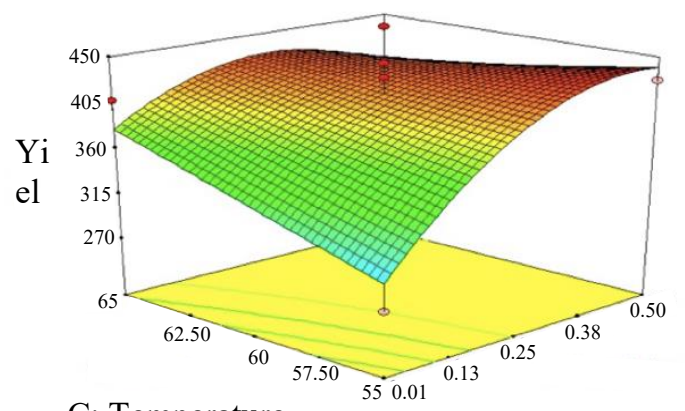

$\mathrm{C}$ : Temperature

B: Concentration

(B)

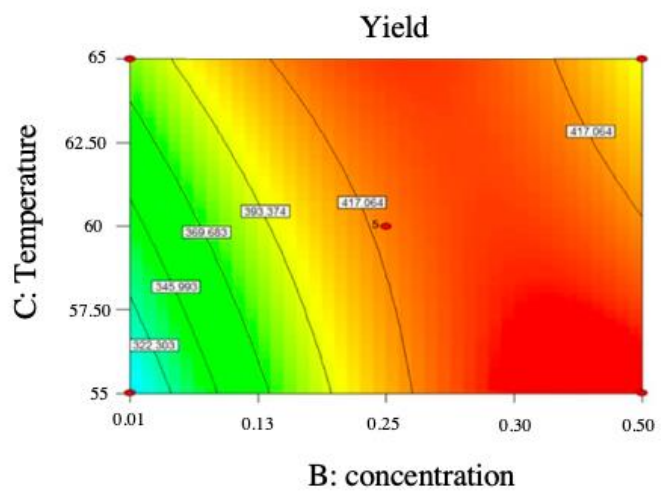

Fig. 6. (A) 3D response surface and (B) contour picture plots between extraction parameters (concentration, temperature) and yield.

Table 4. Factor and level of Box-Behnken design

\begin{tabular}{|l|c|c|}
\hline \multirow{2}{*}{ Parameter } & \multicolumn{2}{|c|}{ Optimum value } \\
\cline { 2 - 3 } & $\begin{array}{c}\text { Predicted } \\
\text { values }^{\mathrm{a}}\end{array}$ & $\begin{array}{c}\text { Experimental } \\
\text { values }^{\mathrm{b}}\end{array}$ \\
\hline Concentration (\%) & 0.48 & 0.48 \\
\hline Time (min) & 1.01 & 1.01 \\
\hline Temperature $\left({ }^{\circ} \mathrm{C}\right)$ & 56.53 & 57 \\
\hline $\begin{array}{l}\text { Chondroitin sulfate } \\
\text { yield (mg/100g dry) }\end{array}$ & 444.566 & 415.59 \\
\hline
\end{tabular}

Additionally, model validation experiments were performed using the predicted optimum extraction conditions from RSM (Table 4). The predicted optimum extraction conditions for the maximum yields of chondroitin sulfate contents were determined at an enzyme concentration $0.48 \%$, extraction temperature of $56.53{ }^{\circ} \mathrm{C}$ and extraction times 0.96 hours. This predicted optimum extraction conditions will provide an extraction yield of $444.566 \mathrm{mg} / 100 \mathrm{~g}$ dried sample. From this validation experiment, the chondroitin sulfate yield at $415.59 \mathrm{mg} / 100 \mathrm{~g}$ dried was obtained, which showed model error of about $6.51 \%$. This result showed that the actual experimental value was in good agreement with the predicted values obtained from the quadratic model [35-38]. Hence, the response surface modeling can be 
applied effectively to the prediction of extraction of chondroitin sulfate from Bohadschia argus.

\section{Conclusion}

RSM was employed to understand the relationship between the extraction parameters and yield of chondroitin sulfate. According to ANOVA, the effects of enzyme concentration on extraction yield were significant. And the best conditions to obtain a high yield of chondroitin sulfate content in the extracts were determined as enzyme concentration $0.48 \%$, extraction time of $1.01 \mathrm{~h}$., extraction temperature of $56.53{ }^{\circ} \mathrm{C}$, with the maximum yield of chondroitin sulfate 415.59 $\mathrm{mg} / 100 \mathrm{~g}$ dry. Further studies are required to deduce the structure and the physiological activity of the chondroitin sulfate from Bohadschia argus.

\section{Acknowledgment}

Authors would like to thank to Wonnapob Co., Ltd. for financial support and raw materials used in this study, also King Mongkut's University of Technology North Bangkok (KMUTNB-PHD-64-02, KMUTNB-BasicR64-37) and National Research Council of Thailand (NRCT) for financial supports.

\section{References}

1. V. Lobo, A. Patil, A. Phatak, N. Chandra, Free radicals, antioxidants and functional foods: Impact on human health, Pharmacognosy Reviews, $\mathbf{4 , 8}$ (2010): 118-126

2. D. Uebelhart, M. Malaise, R. Marcolongo, F. Vathaire, M. Piperno, E. Mailleux, Intermittent treament of knee osteoarthritis with oral chondroitin sulfate: a one-year, randomized double-blind, multicenter study versus placebo, Osteoarthritis Cartilage, 12,4 (2004): 269-76

3. T. Nakano, M. Betti, Z. Pietrasik, Extraction, Isolation and Analysis of Chondroitin Sulfate Glycosaminoglycans, Recent Patents on Food, Nutrition and Agriculture, 2,1 (2010): 61-74

4. S. Bordbar, F. Anwar, N. Saari, High-value components and bioactives from sea cucumbers for functional foods-a review, Marine Drugs, 9,10 (2011): 1761-805

5. C.C. yu, W.Y. yan, D.Z. Hua, C. Hong S. Jun, Optimization of microwave-assisted extraction of chondroitin sulfate from tilapia byproduct by $r$ esponse surface methodology, (International Conference on Consumer Electronics,

Communications and Networks ,2011)

6. M. Vigan, Allergic contact dermatitis caused by sodium chondroitin sulfate contained in a cosmetic cream. Contact Dermatitis, 70,6 (2014): 383-384

7. T. Qiu, D. Wu, L. Yang, H. Ye, Q. Wang, Z. Cao, Exploring the Mechanism of Flavonoids Through systematic Bioinformatics Analysis, Frontiers in Pharmacol, 9 (2018): 918
8. K. Krebuansang, A. Swatdipong, S. Sammipak, Genetic diversity of Saccostrea forkali rock oyster in the gulf of Thailand, Applied Science and Engineering Progress, 13,2 (2020): 158-165

9. L. Luo, M. Wu, L. Xu, J. Xiang, F. Lu, Comparison of physicochemical characteristics and anticoagulant activities of polysaccharides from three sea cucumbers, Marine Drugs, 11,2 (2013): 399-417

10. E. Siahaan, R. Panggestuti, H. Munandar, S.K. Kim, Cosmeceuticals Properties of Sea Cucumber : Prospects and trends, Cosmetics, 4,3 (2017): 26

11. P. Budzinski, M. Maimeun, P. Mutrakilcharoen, B. Wonganu, M. Sriariyanun, Profiling analysis of fatty acid and collagens obtained from sea cucumber, E3S Web of conference 141,03006 (2020)

12. J. Vazquez, J. Fraguas, R. Novoa-Carvallal,R. Reis, L. Antelo,R. Perez-Martin, Isolation and Chemical Characterization of Chondroitin Sulfate from Cartilage By-Products of Blackmouth Catshark (Galeus melastomus), Marine Drugs. 16,10 (2018): 344

13. G. Yoo, I. Lee, S. Park, N. Kim, J. Park, S. Kim, Optimization of Extraction Conditions for Phenolic Acids from the Leaves of Melissa officinalis L. Using Response Surface Methodology, Pharmacognosy Magazine, 14,54 (2018):155-61

14. S. Akkaravathasinp, P. Narataruksa, C. Prapainainar, Optimization of semi-batch reactive distillation using response surface method: case study of esterification of acetic acid eith methanol in a process simulation, Applied Science and Engineering Progress, 12,3 (2019): 209-215

15. P. Morreale, R. Manopulo, M. Galati, L. Boccanera, G. Saponati, L. Bocchi, Comparison of the anti-inflammatory efficacy of chondroitin sulfate and diclofenac sodium in patients with knee osteoarthrist osteoarthritis, J. Rheumatol. Journal Rheumatol, 23,3 (1996): 13851391

16. L. Bucsi, G. Poor, Efficacy and tolerability of oral chondroitin sulfate as a symptomatic slow-acting drug for osteoarthritis (SYSADOA) in the treatment of knee osteoarthritis, Osteoarthritis Cartilage 6 (Suppl. A), 31,36 (1998)

17. F. Ronca, L. Palmieri, Anti-inflammatory activity of chondroitin sulfate, Osteoarthritis Cartilage 14,21 (1998)

18. D. Uebelhart, M. Malaises, R. Marcolongo, F. DeVathairell, M. Piperno, E. Mailleux, A. Fioravanti, L. Matoso, E. Vignon, Intermittent treatment of knee osteoarthritis with oral chondroitin sulfate: a one year, randomized, double blind, multicenter study versus placebo, Osteoarthr, Cartilage, 12,4 (2004) 269-276 DOI: 10.1016/j.joca.2004.01.004.

19. X.M. Luo, G.J. Fosmire, R.M. Leach, Chicken keel cartilage as a source of chondroitin sulfate, Poultry Science, 81,7 (2002): 1086-1089.

20. S.K. Sikder, A. Das, Isolation and characterization of glycosaminoglycans (mucopolysaccharides) 
from the skin of the fish Labeo rohita, Carbohydrate Research, 71,1 (1979): 273-285.

21. A. Hjerpe, B. Engfeldt, T. Tsegenidis, Analysis of the acid polysaccharides from squid cranial cartilage and examination of a novel polysaccharide, Biochimica et Biophysica Acta, 754,1 (1983): 85-91.

22. D.H. Vynios, A. Aletras, C.P. Tsiganos, T. Tsegenidis, C.A. Antonopoulos, A. Hjerpe, B. Engfeld, Proteoglycans from squid cranial cartilage extraction and characterization, Comparative Biochemistry and Physiology, 80,4 (1985): 761766.

23. G.S. Harper, P.G. Allingham, X. Qiu, Cartilage Co-Products Commercial Development from Alternative Production Species, (RIRDC Publication, Germany, 2000)

24. T. Sumi, H. Ohba, T. Ikegami, M. Shibata, T. Sakaki, I. Sallay, S.S. Park. Method for the preparation of chondroitin sulfate compounds. (US Patent 6,342,367, 2002)

25. P. Hoffman, T.A. Mashburn, Proteinpolysaccharide of bovine cartilage. I: Extraction and electrophoretic studies, Journal of Biological Chemistry, 242,17 (1967) 3799-3804.

26. S.W. Sajdera, V.C. Hascall, Protein polysaccharide complex from bovine nasal cartilage, Journal of Biological Chemistry, 244,1 (1969): 77-87.

27. N.K. Karamanos, A. Syrokou, P. Vanky, M. Nurminen, A. Hjerpe, Determination of 24 variously sulfated galactosaminoglycan and hyaluronan derived disaccharides by high performance liquid chromatography, Analytical Biochemistry, 221,1 (1994) 189-199

28. Y. Lye, N. Salih, J. Salimon, Optimization of partial epoxidation on Jatropa curcas oil base methyl linoleate using urea hydrogen peroxide and methyltrioxorhenium catalyst. Applied Science Engineering Progress, 14,1 (2021): 89-99

29. R. Pangestuti, Z. Arifin, Medicinal and health benefit effects of functional sea cucumbers. Journal Tradit Complement Medicine, 8,3 (2018): 31-51

30. W. Garnjanagoonchorn, L. Wongekalak, A. Engkagul, Determination of chondroitin sulfate from different sources of cartilage. Chemical
Engineering and Processing: Process Intensification, 46,5 (2007): 465-71

31. A. Ahmad, M.U. Rehman, A.F. Wali, H.A. ElSerehy, F.A. Misned, S.N. Maodaa, H.M. Aljawdah, T.M. Mir, Box- Behnken Response Surface Design of Polysaccharide Extraction from Rhododendron arboreum and the Evaluation of Its Antioxidant Potential Molecules, 25,17 (2020): 3835

32. H. C. Tran, H. A. T. Le, T. T. Le, and V. M. Phan, Effects of enzyme types and extraction conditions on protein recovery and antioxidant properties of hydrolysed proteins derived from Defatted Lemna minor, Applied Science and Engineering Progrss, (2021).

33. N.T.L. Vien, P.B. Nguyen, L.D.C. Cuong, T.T.T. An, D.T.A. Dao, Optimization of papain hydrolysis condition for release of glycosaminoglycans from the chicken keel cartilage. Chemical engineering food and biotechnology, 1878,1 (2017): 020009

34. V. Coulson-Thomas, T. Gesteira, Dimethylmethylene Blue Assay (DMMB). (Bio Protocol, 4,18 2020)

35. P. Pangsri, T. Wuttipornpun, W. Songserm, Mannanase and Cellulase Enzyme Production from the Agricultural Wastes by the Bacillus subtilis P25 Strain, Applied Science Engineering Progress, 14,3 (2021): 425-434

36. E.J. Panakkal, M. Sriariyanun, J.Ratanapoompinyo, P. Yasurin, K. Cheenkachorn, W. Rodiahwati, P. Tantayotai, Influence of Sulfuric Acid Pretreatment and Inhibitor of Sugarcane Bagasse on the Production of Fermentable Sugar and Ethanol. Applied Science Engineering Progress, 15,1 (2022)

37. L.K. Akula, R.K. Oruganti, D. Bhattacharyya, K.K. Kurilla. Treatment of Marigold Flower Processing Wastewater Using a Sequential BiologicalElectrochemical Process, Applied Science Engineering Progress, 14,3 (2021): 525-542

38. M. Bahadi, N. Salih, J. Salimon. D-Optimal Design Optimization for the Separation of Oleic Acid from Malaysian High Free Fatty Acid Crude Palm Oil Fatty Acids Mixture Using Urea Complex Fractionation, Applied Science Engineering Progress, $\quad 14,2 \quad$ (2021): $\quad$ 175-186 